\title{
Preliminary Analysis of Intention to Purchase Halal Cosmetics
}

\author{
Ainin Sulaiman ${ }^{1 \star}$, Siti Qhairunissa Ramli ${ }^{1}$,Nursyamimi Zawani Mohd Shoid ${ }^{1}$, Nur Haslina Mohamad ${ }^{2}$, \\ Norazlin Mohd Azman ${ }^{2}$
}

${ }^{1}$ UM Halal Research Centre, Institute of Research Management and Monitoring, University of Malaya, 50603 Kuala Lumpur, Malaysia ${ }^{2}$ Faculty of Syariah and Law, UniversitiSains Islam Malaysia, Bandar BaruNilai, 71800, Nilai, Negeri Sembilan, Malaysia

Abstract: The demand for halal cosmetics by consumers is seen to be increasingly growing in the last two years. The increase in demand is influenced by several factors such as psychological, product quality, religiosity, consideration for the future and attitude. Hence, this study aims to examine the factors that influence the purchase of halal cosmetics among Malaysians. This paper presents the results of a pilot study. Empirical data were collected via the survey questionnaire. A total of 129 responses was collected and used for analysis. Using the correlation test it was found that there is a relationship between intention to purchase with attitude, psychological, product quality, religiosity and consideration for the future. Nevertheless, the strength of the relationship varies. The strength of the relationship is highest for attitude and lowest for psychological. The results of this study will be used to refine the instrument and subsequently used to collect data from a larger pool of respondents.

Keywords: attitude;consideration for the future;intention to purchase; psychological;religiosity

Received: 30th November 2019

Accepted: 27th Marc 2020

Published Online: 24th April 2020
${ }^{*}$ Correspondence:

AininSulaiman,UM Halal Research Centre, Institute of Research Management and Monitoring, University of Malaya, 50603 Kuala Lumpur, Malaysia; ainins@um.edu.my

Citation: Sulaiman, A., Ramli, S. Q., Shoid, N. Z. M., et al. Preliminary analysis of intention to purchase halal cosmetics. J Halal Ind Serv 2020; 3(Special Issue): a0000075.https://doi.org/10.3687/jhis.a0000075

\section{Introduction}

The global halal market size is expected to reach USD 9.71 trillion by 2025(Adroit Market Research, 2019), while the global halal cosmetics market is expected to reach USD 54.16 million by 2022 (Allied Market Research, 2017). This figure illustrates that the demand for halal cosmetic products will be increasing which is due to several factors. Among the factors are the increase in purchasing power of the growing Muslim population and also the desire of Muslim society to associate their interest in cosmetic products that adhere to religious loyalties. Hence, the emergence of the term halal cosmetics.

Halal cosmetics are cosmetic products that contain ingredients permitted under the Shariah law and fatwa and fulfil the following conditions: 1) do not consist of or contain any part or matter of an animal that is prohibited by Shariah law and fatwa for a Muslim to consume or that has not been slaughtered in accordance with Shariah law and fatwa; 2) do not contain anything which is najs according to Shariah law and fatwa; 3) do not intoxicate according to Shariah law and fatwa; 4) do not contain any part of a human being or its yield which is not allowed by Shariah law and fatwa; 5) are not poisonous or hazardous to health; 6) have not been prepared, processed or manufactured using any instrument that is contaminated with najs according to Shariah law and fatwa; and 7) have not in the course of preparing, processing or storing been in contact with, mixed, or in close proximity to any materials that fail to satisfy items (1) and (2)(Department of Standards Malaysia, 2019).

In Malaysia, for a cosmetic product to be labelled as halal, the cosmetic manufacturers have to obtain the halal certification and they have to ensure that they comply with the standards and conditions set by the National Pharmaceutical Regulatory Agency (NPRA) as well as the Department of Islamic Development Malaysia (JAKIM).

The demand for halal cosmetics is expected to increase and this has spurred the growth of the halal cosmetics industry in Malaysia and worldwide. The manufacturers both big or small have invested huge capital to participate in the industry and generally would want their business to sustain over a longer period of time. One way to do so, is to ensure there will be a demand for the products. Hence, the need to identify factors that may contribute to the increase in demand. Knowing these factors would allow the manufacturers to strategizetheir marketing plans.

A review of the literature revealed that there have been several studies such as Abd Rahman et al.(2015); Ahmad and Omar (2016) and Aliet al.(2018), conducted to examine factors that influence the intention to purchase halal cosmetics. Abd Rahman et al.(2015)focused on religiosity and attitude while Ahmad and Omar (2016)focused only on attitude and Ali et al. (2018)concentrated on branding factors. This study would like to fill in the literature gap by studying the influence of religiosity, attitude and brand on purchase intention. In addition, the study also incorporates two individualscharacteristics factors i.e. psychological as well as an individual's consideration for the future (CFC). Hence, the aim of this study is to examine whether religiosity, attitude, brand psychological and CFC influence the intention to purchase halal cosmetics.

This paper proceeds by highlighting literature pertaining to intention to purchase cosmetics in general and halal cosmetics in particular followed by a discussion on the methodology used to collect the empirical data. This is then followed by the discussion on the results and conclusions of the study whereby future research and research limitations are described.

\section{Literature Review}

Purchase intentioncan be defined as consumers' power of making a decision for purchasing particular products and services that are available in the market(Rani and Krishnan, 2018). According to Garg and Joshi (2018)purchase intention also re- 
fers to the mental stage in the decision-making process where the consumer has developed an actual willingness to act toward an object or brand. Hence, the tendency of a person to take a buying action with regard to his/her attitude towards a product can be interpreted as purchase intention as suggested byHanzaeeandRamezani(2011).It could be explained that the interest of purchase is a form of behaviour or a positive attitude towards an object, so as to make an individual try to use or own the object even though he/she must spend some money or make some sacrifice (Hussin et al., 2013).

A review of the literature suggests that there are several factors that influence the intention to purchase halal cosmetics. This paper focusses on five factors i.e. religiosity, attitude, brand, psychological and CFC.The reasons these factors were chosen are discussed in the following paragraph.

Attitude and brand were chosen as most of the past studiesby Abd Rahman et al. (2015), Hussin et al. (2013); Haque et al. (2018);Hashim and Musa (2013) and Foster et al. (2016), included these two factors, thus illustrating their importance, therefore included in this study. Some authorssuch as Abd Rahman et al. (2015), Garg and Joshi (2018) have illustrated that religiosity is a key influencer of halal products such as halal cosmetics and must be included when studying intention to purchase any halal product. The fourth factor, psychological was hypothesised to have an effect on purchasing of any goods; consequently, it has been suggested by many to be incorporated in studying purchase intention (Fathali and Kheyri, 2014)(Quintal et al., 2016).Finally, CFC was included in the study as it is a factor that measures a person's perception towards the future(Hassan, 2014)(Ottman, 2017).The more a person cares for the future, the more environmentally friendly he/she will be and subsequently will purchase more environmentally friendly products such as halal cosmetics.

\section{Religiosity}

In many societies, religion plays an effective role in shaping food habits (Wilson \& Liu, 2011)and religious commitments play a critical role in people'slives through shaping beliefs, knowledge and attitude(Ireland \& Rajabzadeh, 2011).The demand for Halal products today is rapidly increasing since the consumers are becoming more religious through knowledge and information and are more concerned towards halal products (Rani \& Krishnan, 2018).Religious influences behaviour more compared to knowledge pertaining to halal matters and there is a significant difference in respondents'behaviour between halal food products and halal cosmetic products (Abd Rahman, 2015). The overall decision-making process, starting from selecting the product to making purchases and eventually its consumption extensively relies on individuals' degree of commitment toward their respective religion(Haque et al., 2018).The religious and safety concepts associated with the halal cosmetics product influence the customers to purchase it. In addition to this, Garg and Joshi (2018)have also proved that Muslims adhere to their Islamic values as a source of reference before making any reasonable spending.

\section{Attitude}

Attitude could be described as the feeling and perception that one has towards a single thing (Haque et al., 2018). According to Abd Rahman et al. (2015), and Hashim and Musa (2013), consumers' attitudes have a positive impact on their intentions to buy a product. Moreover, consumers' attitude towards the purchase of halal products is more likely to be positive if the source of information obtained is from the religious authorities or leaders (Ahmad and Omar, 2016). Subsequently, many researchers Haqueet al.(2018); Briliana and Mursito (2017) andJawahar and Tamizhjyothi (2013)discovered that attitude significantly affectsthe purchase intention toward halal products such as food and cosmetics.

\section{Brand}

Consumers' overall judgment on the superiority of a product is normally associated with the perceived quality of a brand (Ali et al.,2018). Consumers purchase only familiar and well-established brands because they do not always spend a great deal of time or cognitive effort in making purchase decisions and often try to minimise decision-making(Hussin et al.,2013). Businesses that embrace their brands fully are the ones that people will remember (Foster et al., 2016).Hussinet al. (2013)found that brand familiarity positively influenced shoppers' purchase intention while examining traditional retail stores while Meng (2014) found brand awareness affected the intention to purchase halal cosmetics among university students.

\section{Psychological Factors}

Psychological factors include motivation, personality and emotions which are all influential factors that affect consumer decision making(Vainikka, 2015). Motivation can be described as an "energising force"by Hawkins (2010)that activates certain behaviours that in turn provides purpose and direction to these behaviours. Personality is a set of unique characteristics which lead to permanent reactions towards the environment (Azizpour, 2016). The concept of personality can be helpful in analysing the marketing and related variables (Ebrahimi, 2012).Emotions can be defined as strong, uncontrollable feelings that have effectson behaviour(Vainikka, 2015).Fathali and Kheyri (2014)reported that psychological characteristics affect the consumers' attitude toward luxury products and the quality of the products. Quintialet al. (2016)also insisted that psychological factors affect the purchasing of goods.

\section{Consideration for Future}

The Malaysian Government has likewise reacted positively to the green issue, as consumers have become more affluent and concerned about the environment, safety and animal welfare(Hassan, 2014).Marketers have realised that the growing concern of consumers toward the environment is because of an apprehension that the planet is losing its ability to sustain human life(Ottman, 2017). According to a worldwide survey conducted by Nielsen Company Nielsen (2015)in 2015,the Asia-Pacific area has the second highest number of consumers who wish for increased availability of green (halal) products in the market. Past research and empirical evidence stressed the importance of environmental concern as one of the major factors in consumer decision-making(Hassan, 2014).

Based on the discussion above, the theoretical framework is formulated (Figure 1). 


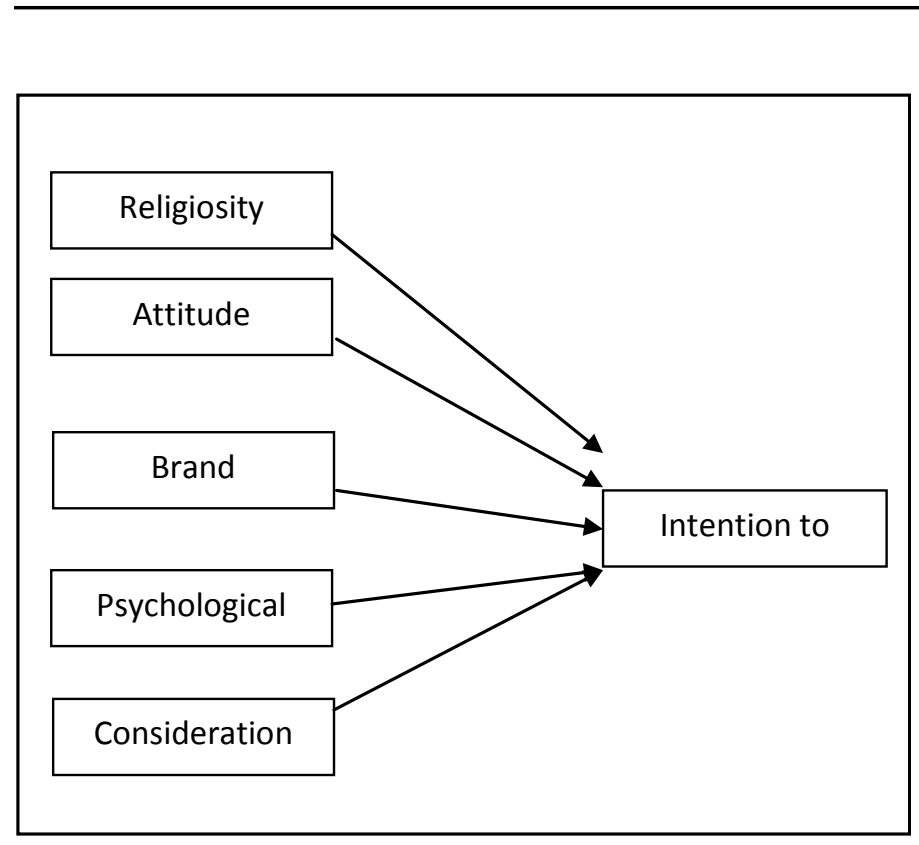

Figure 1. Research model adapted from Lada et al. (2009), Briliana and Mursito (2017), Jawahar and Tamizhjyothi (2013), Meng (2014), Bailey (2011) and Chin et al. (2018).

\section{Methodology}

The empirical data used for this paper were collected via a survey questionnaire. The questionnaire was distributed to Malaysians living within the Klang Valley area. This area was selected because it is the most populated area in Malaysia. As this study is a pilot study, the respondents were randomly selected. Two enumerators were stationed at selected public places within the Klang Valley. They then approached individuals that walked pass by them. After the respondents had agreed to participate, the aim of the survey was explained to them and they were informed that they are free to walk away if they do not want to participate in the survey. Most of the respondents filled in the questionnaire on the spot. Data collection was carried out over a period of four weeks. A total of 145 questionnaires was distributed, however,only 129 were used for analysis as 16 were found to be incomplete.

The questionnaire consists of two main sections: Section A consists of items that measure the factors influencing purchase intention, while Section B requires the respondents to fill in their demographic details. The questionnaire was formulated based on past studies (Table 1). The demographics are based on Chin and Harizan (2017)while the factors influencing purchase intention were adopted from Jawahar and Tamizhjyothi (2013);Meng(2014); Briliana and Mursito (2017); Chin et al. (2018); and Bailey (2011). Intention to purchase was adopted from Lada et al.(2009).

Table 1. Constructs, number of items, and sources

\begin{tabular}{|l|l|c|}
\hline Construct & Source & $\begin{array}{l}\text { No. of } \\
\text { items }\end{array}$ \\
\hline $\begin{array}{l}\text { Intention to pur- } \\
\text { chase }\end{array}$ & $\begin{array}{l}\text { Ladaet al., 2009 } \\
\text { Briliana and Mursito, } \\
\text { Religiosity }\end{array}$ & 6 \\
\hline
\end{tabular}

\begin{tabular}{|l|l|c|} 
Attitude & $\begin{array}{l}\text { Jawahar and Tamizhjyo- } \\
\text { thi, 2013 }\end{array}$ & 8 \\
\hline Brand & Meng, 2014 & 6 \\
\hline Psychological & Bailey, 2011 & 4 \\
\hline $\begin{array}{l}\text { Consideration for } \\
\text { future }\end{array}$ & Chin et al.,2018 & 4 \\
\hline
\end{tabular}

Items (33 in total) in Section A were measured using a Likert scale, ranging from 1 (Strongly disagree) to 5 (Strongly agree). The empirical data were analysed using the Statistical Package for the social sciences application (SPSS) for statistical tests such as descriptive, reliability test, factor analysis, and correlation test.

\section{Discussion of Findings}

As mentioned earlier a total of 129 responses was analysed and their profile is summarised in Table 2 . The majority of the respondents were female, between 26 to 50 years old and earning more than RM2,000.00 a month. This sample of respondents although randomly selected is reflective of consumers that have the intention to purchase halal cosmetics as most of them have a purchasing power of their own. As this is a pilot study, the targeted respondents were all Muslims as it is assumed that they would be the main consumers that are interested to buy halal cosmetics.

Table 2. Profile of respondents

\begin{tabular}{|c|c|c|c|}
\hline Category & Items & $\begin{array}{c}\text { Freq. }(N= \\
129)\end{array}$ & $\begin{array}{c}\text { Percent } \\
(\%)\end{array}$ \\
\hline \multirow[t]{2}{*}{ Gender } & Male & 28 & 21.7 \\
\hline & Female & 101 & 78.3 \\
\hline \multirow[t]{4}{*}{ Age } & $18-25$ years & 18 & 14.0 \\
\hline & $26-35$ years & 50 & 38.8 \\
\hline & $36-50$ years & 47 & 36.4 \\
\hline & $>50$ years & 14 & 10.9 \\
\hline \multirow[t]{3}{*}{ Education } & Diploma & 64 & 49.6 \\
\hline & Bachelor & 44 & 34.1 \\
\hline & Master/PhD & 21 & 16.3 \\
\hline \multirow{5}{*}{$\begin{array}{l}\text { Income per } \\
\text { month (RM) }\end{array}$} & RM0-1,999 & 33 & 25.6 \\
\hline & $\begin{array}{l}\text { RM2,000- } \\
2,999\end{array}$ & 49 & 38.0 \\
\hline & & 32 & 24.8 \\
\hline & $\begin{array}{c}\text { RM3,000- } \\
3,999\end{array}$ & 15 & \\
\hline & $>\mathrm{RM} 4,000$ & & \\
\hline \multirow{4}{*}{$\begin{array}{l}\text { Occupation } \\
\text { (Sector) }\end{array}$} & Government & 93 & 72.1 \\
\hline & Private & 17 & 13.2 \\
\hline & Student & 18 & 14.0 \\
\hline & Self-Employed & 1 & 00.8 \\
\hline
\end{tabular}


One of the first statistical tests that was carried out was the descriptive and reliability test although the items were adopted from past studies. The reason is that the constructs (the independent variable) were studied separately from one another whereas in this study the five constructs were studied as a full model. From Table 3, it can be observed that the mean values of all the constructs were very high i.e. more than 3.5 for all constructs showing the high level of agreeableness for each construct and the values of the standard deviation range from 0.62 to 0.81 . The values of the Cronbach's Alpha were all between 0.8 to 0.9 illustrating that the constructs are reliable and can be used for further analysis.

Table 3. Descriptive statistics and reliability analysis

\begin{tabular}{|l|c|c|c|}
\hline \multicolumn{1}{|c|}{ Factors } & Mean & SD & $\begin{array}{c}\text { Cronbach's } \\
\text { Alpha }\end{array}$ \\
\hline $\begin{array}{l}\text { Intention to } \\
\text { purchase } \\
\text { Religiosity }\end{array}$ & 4.4186 & .71477 & .849 \\
\hline Attitude & 4.1876 & .69721 & .889 \\
\hline Brand & 3.9118 & .62410 & .830 \\
\hline Psychological & 3.9703 & .65632 & .845 \\
\hline $\begin{array}{l}\text { Consideration for } \\
\text { future }\end{array}$ & 3.8198 & .81128 & .895 \\
\hline
\end{tabular}

Subsequently, factor analysis was carried out to explore the possible underlying structure of the 5 constructs without imposing any preconceived structure on the outcome as suggested by Hair et al.(2014). By performing the exploratory factor analysis (EFA), the number of constructs and the underlying factor structure were identified. In performing the analysis, the cut-off score chosen was 0.4 , hence, any values less than 0.4 were not taken into consideration based on Ertz et al.'s (2016) study. The results of the analysis (Table 4) illustrated that all 27 items were loaded into 5 factors as per literature. Nevertheless, it was found that most of the items were loaded into Factor 1 and only 1 item (ATT26) was loaded into Factor 5. In addition, 7 items which were loaded under Factor 1 were also loaded under other factors although the values are smaller than those loaded under Factor 1, thus indicating that they are loaded under Factor 1 . These results are not consistent with the literature as it illustrated that the items are loaded under Factor 1, which actually can be categorizedas attitude. Consequently, the researchers will conduct another factor analysis test with the actual data collection to examine whether the items will be loaded into 5 different factors as indicated by past literature or the results would be the same as in this pilot study.

Table 4. Factor analysis results.

\begin{tabular}{|c|c|c|c|c|c|}
\hline Item & $\mathbf{1}$ & $\mathbf{2}$ & $\mathbf{3}$ & $\mathbf{4}$ & $\mathbf{5}$ \\
\hline CFC36 & .799 & & & & \\
CFC39 & .796 & & & & \\
\hline CFC38 & .789 & & & & \\
\hline ATT24 & .762 & & & & \\
\hline R43 & .755 & & & & \\
\hline R40 & .753 & & & & \\
\hline ATT23 & .748 & & & & \\
\hline B33 & .732 & & & & \\
\hline
\end{tabular}

\begin{tabular}{|c|c|c|l|l|l|}
\hline CFC37 & .732 & & & & \\
\hline R44. & .730 & & & & \\
\hline R42 & .722 & & & & \\
\hline ATT28 & .711 & & & & \\
\hline P45 & .701 & -.514 & & & \\
\hline P46 & .698 & -.542 & & & \\
\hline B32 & .696 & .405 & & & \\
\hline ATT22 & .688 & & & & \\
\hline P47 & .687 & & & & \\
\hline B31 & .672 & & & & \\
\hline B35 & .668 & & & & \\
\hline R41 & .660 & & -.422 & & \\
\hline P48 & .639 & & & & \\
\hline B32 & .621 & & & & \\
\hline ATT29 & .580 & .451 & & & \\
\hline ATT27 & .551 & & .409 & & \\
\hline ATT25 & .547 & & & & \\
\hline B34 & .538 & & & & -.509 \\
\hline ATT26 & & & & .427 & .611 \\
\hline *Note: R = Religiosity; ATT = Attitude; B = brand, P = Psychological;
\end{tabular}

$\mathrm{CFC}=$ Consideration for future consequences

After the factor analysis test, the correlation test was conducted to examine the linear relationship between the intention to purchase with religiosity, attitude, brand, physiological, and CFC. In addition, the linear relationships between the five constructs can also be observed. The results are illustrated in Table 5 .

Table 5. Correlations between constructs.

\begin{tabular}{|c|c|c|c|c|c|c|}
\hline Construct & IP & ATT & Brand & CFC & $\begin{array}{c}\text { Re- } \\
\text { ligi- } \\
\text { osi- } \\
\text { ty }\end{array}$ & $\begin{array}{l}\text { Psy- } \\
\text { cho- } \\
\text { logi- } \\
\text { cal } \\
\end{array}$ \\
\hline $\begin{array}{l}\text { Intention } \\
\text { to purchase } \\
\text { (IP) }\end{array}$ & 1 & .800 & .701 & .744 & .732 & .619 \\
\hline $\begin{array}{l}\text { Attitude } \\
\text { (ATT) }\end{array}$ & & 1 & .763 & .746 & .684 & .601 \\
\hline Brand & & & 1 & .719 & .636 & .590 \\
\hline $\begin{array}{l}\text { Consid- } \\
\text { eration } \\
\text { for future } \\
\text { (CFC) }\end{array}$ & & & & 1 & .734 & .610 \\
\hline Religiosity & & & & & 1 & .657 \\
\hline $\begin{array}{l}\text { Psycholog- } \\
\text { ical }\end{array}$ & & & & & & 1 \\
\hline
\end{tabular}

From Table 5 it can be observed that the strength of the relationship between 'intention to purchase' with all the constructs except 'psychological' is strong with 'attitude' the strongest and 'brand' the lowest. The relationship between 'intention to purchase' and 'psychological' is moderate. Although in Table 
4 all the items from the five constructs were loaded under one factor, the results of the correlations suggest moderate relationship exist between 'attitude' with 'religiosity' and 'psychological', 'brand' with 'religiosity' and 'psychological', 'CFC' with 'psychological' and 'religiosity' with 'psychological'. Generally, these results illustrate that the items in the five constructs actually measure the individual constructs and not factored as one as what was found in Table 4 .

\section{Conclusion}

The aim of this study is to examine factors that influence the intention to purchase halal cosmetics among Malaysian Muslims. This study is a pilot study and this paper presents the preliminary analysis based on 129 respondents. The preliminary results showed there was a linear relationship between 'intention to purchase' with 'religiosity', 'attitude,' 'brand', 'physiological' and 'CFC'. These findings are consistent with past studies that studied the relationship between 'intention to purchase' with 'religiosity'(Abd Rahman et al., 2015); 'attitude'(Abd Rahman et al., 2015; Haque et al. 2018; Briliana \&Mursito, 2017;Jawahar \&Tamizhjyothi,2013); 'brand'(Meng, 2014); psychological'(Quintal, 2016); and CFCNielsen (2015).

The study like any other studies has a few limitations. The first limitation is the sample size. Future study should include a bigger sample of respondents. Second, the respondents were conveniently selected, future research should use stratified random sampling which considers sampling by regions or locations. Third, the items of each construct chosen were selected based on past studies. Future studies must include an expert panel to validate the content before the final questionnaire is distributed. The results of this pilot study will be used to develop a research model, and hypotheses will be formulated and tested to determine whether religiosity, attitude, brand, psychological factor and CFC have any effect on the intention to purchase halal cosmetics.

It must be highlighted here that this study is a pilot study, thus the results are preliminary. Subsequently,the limitations of the study should be used as a guide for the actual study. It is hoped that the findings of the actual study will be used by the halal industry manufacturers to develop their strategies in capturing the halal cosmetics market.

\section{Conflict of Interest} in this work.

The authors declare that there is no conflict of interest

\section{Acknowledgements}

This work was supported in part by the Malaysian Higher Education Consortium of Halal Institutes, Ministry of Education, Malaysia, and in part by the University of Malaya under Grant MO001-2018.

\section{References}

Abd Rahman, A., Asrarhaghighi, E., \& Ab Rahman, S. (2015). Consumers and Halal cosmetic products: Knowledge, religiosity, attitude and intention. Journal of Islamic Marketing, 6(1), 148-163.
Adroit Market Research. (2019). Halal market report Dallas. USA: Ryan Johnson.

Ahmad, S. N. B. \& Omar, A. (2016). Influence of attitude on consumers' behavioralbehavioural intention toward Halal cosmetics in Malaysia. Journal of Business Innovation, 1(1), $57-72$.

Ali, A., Xiaoling, G., Sherwani, M., et al. (2018). Antecedents of consumers' Halal brand purchase intention:An integrated approach. Management Decision, 56(4), 715-735. Retrieved from https://doi.org/10.1108/MD-11-2016-0785.

Allied Market Research. (2017). Halal cosmetics market by product type (personal care products, colourcolour cosmetics, and fragrances), application (hair care, skin care, face care, and beauty care), and distribution channel (online and offline) - global opportunity analysis and industry forecast, 20142022). Canada, USA: Allied Market Research Team; 2017.

Azizpour, R., Abbasnejad, T., \& Siyavooshi, M. (2016). Effective factors on purchasing intention of cosmetics and health products in Tehran city. International Journal of Academic Research in Business and Social Sciences, 6 (11), 449-458.

Bailey, L. (2011). A study of the factors impacting women's purchases of anti-aging skincare products. (Master of Science Degree Thesis).University of Georgia. Retrieved from https://getd. libs.uga.edu/pdfs/bailey_rena_1_201108_ms.pdf.

Briliana, V. \& Mursito, N. (2017). Exploring antecedents and consequences of Indonesian Muslim youths' attitude towards halal cosmetic products: A case study in Jakarta. Asia Pacific Management Review, 22(4), 176-184. Retrieved from https://doi.org:/10.1016/j.apmrv.2017.07.012.

Chin, J., Jiang, B., Mufidah, I., et al. (2018). The investigation of consumers' behaviour intention in using green skincare products: A pro-environmental behaviour model approach. Sustainability,10(11), 1-15. Retrieved from https:// doi.org:/10.3390/su10113922.

Chin, T.K., \& Harizan, S.H.M. (2017). Factors influencing consumers' purchase intention of cosmetic. International Journal of Business and Innovation, 3(1), 01-15.

Department of Standards Malaysia. (2019). MS2634:2019 Halal cosmetics-General requirements. (DHHS Publication No. ICS: 11.040.01). Cyberjaya, Malaysia: Government Printing Office.

Ebrahimi, M. (2012). A survey on effective factors on attitude and intention of consumers to buy fictitious luxury products of clothing industry (Case Study of Sari). New Research-Scientific Quarterly, 3(6), 34-52.

Ertza, M. Karakasb, F. \& Sarigöllüc, E. (2016). Exploring pro-environmental behaviours of consumers: An analysis of contextual factors, attitude, and behaviours, Journal of Business Research, 69 (10), 3971-3980.

Fathali, M. \& Kheyri, B. (2014). Effect of demographical and psychological variables on purchasing intention. New Research Journal on Marketing, 17(2), 12-34. 
Foster, L., Haltiwanger, J., \& Syverson, C. (2016). The slow growth of new plants: Learning about demand? Economica, 83(329), 91-129. Retrieved from https://doi.org/10.1111/ ecca. 12172.

Garg, P. \& Joshi, R. (2018). Purchase intention of "Halal" brands in India: The mediating effect of attitude. Journal of Islamic Marketing, 9(3), 683-694. Retrieved from https://doi. org/10.1108/JIMA-11-2017-0125.

Hair Jr, J. F., Black, W.C., et al. (2014). Multivariate Data Analysis (7th ed.). United Kingdom: Pearson Education.

Hanzaee, K.H. \& Ramezani, M.R. (2011). Intention to halal products in the world markets. Interdisciplinary Journal of Research in Business, 1(5), 1-7.

Haque, A., Anwar, N., Tarofder, A., et al. (2018). Muslim consumers' purchase behavior towards halal cosmetic products in Malaysia. Management Science Letters, 8(12): 1305-1318.

Hashim, A.J.C.M. \& Musa, R. (2013). Modelling the effects on the attitude of young adult urban Muslim women towards halal cosmetic products: New insights for championing the halal economy. International Journal of Education and Research, 1(7), 1-8.

Hassan, S.H. (2014). The role of Islamic values on green purchase intention. Journal of Islamic Marketing, 5(3), 379-395. Retrieved from https://doi:.org/10.1108/JIMA-11-2013-0080.

Hawkins, D. I., Mothersbaugh, D. L., \& Mookerjee, A. (2010). Consumer behaviour building marketing strategy, Special Indian Edition (11th ed.). New York: Mcgraw Hill.

Hussin, S.R., Hashim, H, Yusof, R. N, et al. (2013). Relationship between product factors, advertising, and purchase intention of halal cosmetic. Pertanika Journal of Social Science and Humanities, 21, 85-100.

Ireland, J. \& Rajabzadeh, S.A. (2011). UAE consumer concerns about halal products. Journal of Islamic Marketing, 2(3),274-283. Retrieved from https://doi. org/10.1108/17590831111164796.

Jawahar, J.V. \& Tamizhjyothi, K. (2013) Consumer attitude towards cosmetic product. International Journal of Engineering and Management Research, 3, 1-7.

Lada, S., Tanakinjal, G. H., \& Amin, H. (2009). Predicting intention to choose halal products using theory of reasoned action. International Journal of Islamic and Middle Eastern Finance and Management, 2(1), 66-76. doi: Retrieved from https://doi.org/10.1108/17538390910946276.

Meng, X. (2014). Customer intention to purchase halal cosmetics in Malaysia.(Master's thesis). Universiti Utara Malaysia. Retrieved from http://etd.uum.edu.my/4220/2/s811882_ abstract.pdf.

Nielsen. (2015). Looking to achieve new product success. Nielsen Global New Product Innovation Report 2015; New York, NY, USA: Nielsen. tools, and inspiration for sustainable branding. RoutledgeBerrett: Koehler Publishers.

Quintal, V., Phau, I., Sims, D., et al. (2016). Factors influencing generation Y's purchase intentions of prototypical versus me-too brands. Journal of Retailing and Consumer Services, 30, 175-183. Retrieved from https://doi.org/10.1016/j.jretconser.2016.01.019.

Rani, N.S.A. \& Krishnan, K.S.D. (2018). Factors that influence Malay students in purchasing skincare products in Malaysia. Journal of Business and Retail Management, 13(1), 15-21.

Vainikka, B. (2015). Psychological factors influencing consumer behaviour. (Bachelor Dissertation, Centria University of Applied Sciences, Bachelor. Dissertation.).

Wilson, J.A.J. \& Liu, J. (2011). The challenges of Islamic branding: Navigating emotions and halal. Journal of Islamic Marketing, 2(1), 28-42. Retrieved from https://doi. org/10.1108/17590831111115222.

Ottman, J.A. (2017). The new rules of green marketing: Strategies, 